Article

\title{
Synthesis and Structural Characterization of Two New Main Group Element Carboranylamidinates
}

\author{
Phil Liebing $\mathbb{D}^{\mathbb{2}}$, Nicole Harmgarth, Florian Zörner, Felix Engelhardt, Liane Hilfert $\mathbb{D}^{\text {, }}$, Sabine Busse \\ and Frank T. Edelmann *D \\ Chemisches Institut der Otto-von-Guericke-Universität Magdeburg, 39106 Magdeburg, Germany; \\ phil.liebing@ovgu.de (P.L.); Nicole.Harmgarth@t-online.de (N.H.); fzoerner@outlook.de (F.Z.); \\ fengelh@gwdg.de (F.E.); liane.hilfert@ovgu.de (L.H.); sabine.busse@ovgu.de (S.B.) \\ * Correspondence: frank.edelmann@ovgu.de; Tel.: +49-391-67-58327; Fax: +49-391-67-42933
}

Received: 26 February 2019; Accepted: 11 March 2019; Published: 13 March 2019

check for updates

\begin{abstract}
Two new main group element carboranylamidinates were synthesized using a bottom-up approach starting from $o$-carborane, ortho- $\mathrm{C}_{2} \mathrm{~B}_{10} \mathrm{H}_{12}(1,=1$,2-dicarba-closo-dodecaborane). The first divalent germanium carboranylamidinate, $\mathrm{GeCl}\left[\mathrm{HL}^{\mathrm{Cy}}\right]\left(3,\left[\mathrm{HL}^{\mathrm{Cy}}\right]^{-}=\left[0-\mathrm{C}_{2} \mathrm{~B}_{10} \mathrm{H}_{10} \mathrm{C}(\mathrm{NCy})(\mathrm{NHCy})\right]^{-}\right.$, $\mathrm{Cy}=$ cyclohexyl), was synthesized by treatment of $\mathrm{GeCl}_{2}$ (dioxane) with 1 equiv. of in situ-prepared $\mathrm{Li}\left[\mathrm{HL}^{\mathrm{Cy}}\right]$ (2a) in THF and isolated in $47 \%$ yield. In a similar manner, the first antimony(III) carboranylamidinate, $\mathrm{SbCl}_{2}\left[\mathrm{HL}^{i \mathrm{Pr}}\right]\left(4,\left[\mathrm{HL}^{i \mathrm{Pr}}\right]^{-}=\left[o-\mathrm{C}_{2} \mathrm{~B}_{10} \mathrm{H}_{10} \mathrm{C}\left(\mathrm{N}^{i} \mathrm{Pr}\right)\left(\mathrm{NH}^{i} \mathrm{Pr}\right)\right]^{-}\right)$, was obtained from a reaction of $\mathrm{SbCl}_{3}$ with 1 equiv. of $\mathrm{Li}\left[\mathrm{HL}{ }^{i \mathrm{Pr}}\right]$ in $\mathrm{THF}$ (56\% yield). The title compounds were fully characterized by analytical and spectroscopic methods as well as single-crystal X-ray diffraction. Both compounds $\mathbf{3}$ and $\mathbf{4}$ are monomeric species in the solid state, and the molecular geometries are governed by a stereo-active lone pair at the metal centers.
\end{abstract}

Keywords: boron; carborane; carboranylamidinate; germanium; antimony; crystal structure

\section{Introduction}

Dodecahedral carborane cage compounds of the composition $\mathrm{C}_{2} \mathrm{~B}_{10} \mathrm{H}_{12}$ [1] are of tremendous scientific and technological interest due to a variety of practical applications, including the synthesis of polymers and ceramics [2], catalysts [3-5], radiopharmaceuticals [6], and non-linear optical materials [7]. The novel chelating ligand type of ortho-carboranylamidinates was first synthesized in our laboratory in 2010 by in-situ metalation of o-carborane, ortho- $\mathrm{C}_{2} \mathrm{~B}_{10} \mathrm{H}_{12}(\mathbf{1},=1$,2-dicarba-closo-dodecaborane) with $n$-butyllithium, followed by treatment with 1 equiv. of a 1,3-diorganocarbodiimide [8]. They combine the carborane cage with the versatile chelating amidinate anions, $\left[R C\left(\mathrm{NR}^{\prime}\right)_{2}\right]^{-}[9-12]$ in one ligand system. In the resulting lithium ortho-carboranylamidinates $\mathrm{Li}\left[\left(o-\mathrm{C}_{2} \mathrm{~B}_{10} \mathrm{H}_{10}\right) \mathrm{C}(\mathrm{NR})(\mathrm{NHR})\right](=\mathrm{Li}[\mathrm{HL}]$; 2a: $\mathbf{R}={ }^{i} \operatorname{Pr}, \mathbf{2 b}: \mathrm{R}=\mathrm{Cy}$ (cyclohexyl)), a proton is formally shifted from a carboranyl carbon atom to the amidinate unit, resulting in an amidine moiety acting as a monodentate $\mathrm{N}$-donor functionality (Scheme 1a). The lithium derivatives were further treated with various metal and non-metal chloride precursors to yield carboranylamidinates of e.g., $\mathrm{Sn}(\mathrm{II})$ and $\mathrm{Cr}(\mathrm{II})$ [8], $\operatorname{Rh}(\mathrm{I})$ and $\operatorname{Ir}(\mathrm{I})$ [13-16], $\mathrm{Fe}(\mathrm{II})$ and Fe(III) [17,18], Mo(II), Mn(II), Co(II), Ni(II), Cu(II) [18,19], Ti(IV), Zr(IV), Si(IV), Ge(IV), Sn(IV), Pb(IV), and $\mathrm{P}$ [20-22]. In the case of reactions with $\mathrm{Cp}_{2} \mathrm{TiCl}_{2}, \mathrm{Cp}_{2} \mathrm{ZrCl}_{2}, \mathrm{PhPCl}_{2}$, and various dichlorosilanes $\mathrm{R}_{2} \mathrm{SiCl}_{2}$, formal dehydrochlorination led to complexes with dianionic $\left[\left(o-\mathrm{C}_{2} \mathrm{~B}_{10} \mathrm{H}_{10}\right) \mathrm{C}(\mathrm{NR})_{2}\right]^{2-}\left(=[\mathrm{L}]^{2-}\right)$ ligands having a deprotonated amidine group [20,22]. In a recent study, we have shown that the formation of this product class is preferred for highly Lewis-acidic centers, while "soft" metal centers form stable complexes with the original $\left[\left(0-\mathrm{C}_{2} \mathrm{~B}_{10} \mathrm{H}_{10}\right) \mathrm{C}(\mathrm{NR})(\mathrm{NHR})\right]^{-}\left(=[\mathrm{HL}]^{-}\right)$ligand [22]. In all cases (i.e., for both $[\mathrm{HL}]^{-}$- and $[\mathrm{L}]^{2-}$-type ligands, and independent from the choice of the central atom), the ligand adopts a characteristic $\kappa C, \kappa N$-chelating coordination mode instead of the "normal" $\kappa N, \kappa N^{\prime}$-chelating mode of 
coordinated amidinate anions $[23,24]$. In this contribution, we report the synthesis and full characterization of the first germanium(II) carboranylamidinate as well as the first antimony compound of this type.

a)

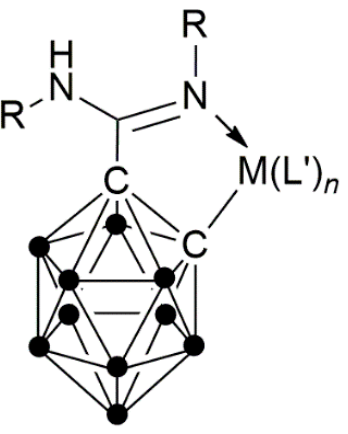

b)

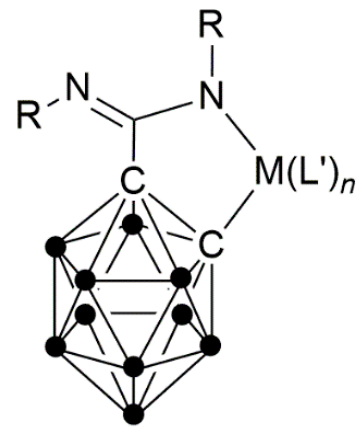

$\mathrm{R}={ }^{i} \mathrm{Pr}, \mathrm{Cy}(=$ cyclohexyl)

$\mathrm{M}\left(\mathrm{L}^{\prime}\right)_{n}=$ metal complex fragment

$\bullet=\mathrm{BH}$

Scheme 1. General schematic representation of carboranylamidinate complexes showing the characteristic $\kappa \mathrm{C}, \kappa N$-chelating coordination mode $[23,24]$, (a) with a monoanionic $\left[\left(o-\mathrm{C}_{2} \mathrm{~B}_{10} \mathrm{H}_{10}\right) \mathrm{C}(\mathrm{NR})(\mathrm{NHR})\right]^{-}\left(=[\mathrm{HL}]^{-}\right)$ ligand, and $(\mathbf{b})$ with a dianionic $\left[\left(o-\mathrm{C}_{2} \mathrm{~B}_{10} \mathrm{H}_{10}\right) \mathrm{C}(\mathrm{NR})_{2}\right]^{2-}\left(=[\mathrm{L}]^{2-}\right)$ ligand.

\section{Results and Discussion}

\subsection{Synthesis and Characterization of $\mathrm{GeCl}\left[\mathrm{HL}^{\mathrm{Cy}}\right]$ (3) and $\mathrm{SbCl}_{2}\left[\mathrm{HL}^{i P r}\right]$ (4)}

The synthetic protocol leading to the title compounds is outlined in Scheme 2. In the first step, the lithium carboranylamidinates $\mathbf{2} \mathbf{a}$ and $\mathbf{2 b}$ were prepared in a one-pot reaction from $o$-carborane (1) and the corresponding carbodiimide. Subsequent reaction of $2 \mathbf{a}$ with 1 equiv. of the readily accessible germanium(II) precursor $\mathrm{GeCl}_{2}$ (dioxane) [25] led to formation of $\mathrm{GeCl}\left[\mathrm{HL}{ }^{\mathrm{Cy}}\right]$ (3) as the first carbonylamidinate of divalent germanium. Compound 3 was isolated in $47 \%$ yield as colorless, block-like crystals after recrystallization from toluene. In a similar manner, the first antimony(III) carboranylamidinate, $\mathrm{SbCl}_{2}\left[\mathrm{HL}^{i \mathrm{Pr}}\right]$ (4) was prepared from $\mathrm{SbCl}_{3}$ and 1 equiv. of $\mathrm{Li}\left[\mathrm{HL}^{i P r}\right](2 \mathbf{b})$ in THF. After crystallization from toluene, compound 4 could be isolated in $56 \%$ yield as colorless, needle-like crystals which, like 3 , are significantly moisture-sensitive. In both cases, the complex having a $[\mathrm{HL}]^{-}$-type ligand is the only identified product, and no evidence for the formation of products with $[\mathrm{L}]^{2-}$ ligands has been observed. Consequently, the divalent germanium precursor turned out to react with $\mathrm{Li}[\mathrm{HL}]$ in a similar manner as $\mathrm{GeCl}_{4}$ [22], while the reaction of $\mathrm{SbCl}_{3}$ took a different course than that of $\mathrm{PhPCl}_{2}[20]$.

Both title compounds 3 and 4 were fully characterized through the usual set of elemental analyses and spectroscopic methods. The ${ }^{1} \mathrm{H}$ - and ${ }^{13} \mathrm{C}$-NMR data of 3 were in good agreement with the expected composition. In the ${ }^{1} \mathrm{H}-\mathrm{NMR}$ spectrum, a singlet at $\delta 8.06 \mathrm{ppm}$ could be assigned to the uncoordinated $\mathrm{NH}$ functionality of the amidine unit. High molecular mass peaks in the mass spectrum of 3 were detected at $m / z 457\left(87 \%\right.$ rel. int.) $[\mathrm{M}-\mathrm{H}]^{+}$and $422\left(13 \%\right.$ rel. int.) $[\mathrm{M}-\mathrm{Cl}]^{+}$. The absence of peaks at higher molecular masses confirmed the monomeric nature of 3 . In the IR spectrum of 3 , typical bands of the amidine moiety were observed at $3403 \mathrm{~cm}^{-1}\left(v_{\mathrm{N}-\mathrm{H}}\right), 1577 \mathrm{~cm}^{-1}\left(v_{\mathrm{C}=\mathrm{N}}\right)$, and $1260 \mathrm{~cm}^{-1}\left(v_{\mathrm{C}-\mathrm{N}}\right)$. A medium strong band at $2584 \mathrm{~cm}^{-1}$ can be assigned to the carborane cage $\left(v_{\mathrm{B}-\mathrm{H}}\right)$ [22]. The antimony derivative 4 was fully characterized in the same manner. The ${ }^{1} \mathrm{H}-\mathrm{NMR}$ spectrum of 4 displayed a characteristic signal pattern of the two chemically inequivalent isopropyl groups (two doublets and two septets). In this case, the $\mathrm{NH}$ resonance could not be observed. However, the presence of a $\left[\mathrm{HL}{ }^{i \mathrm{Pr}}\right]^{-}$ligand in 4 was confirmed by a sharp $v_{\mathrm{N}-\mathrm{H}}$ band at $3396 \mathrm{~cm}^{-1}$ in the IR spectrum. Additional characteristic bands of the amidine group were observed at $1605 \mathrm{~cm}^{-1}\left(v_{\mathrm{C}=\mathrm{N}}\right)$ and $1251 \mathrm{~cm}^{-1}\left(v_{\mathrm{C}-\mathrm{N}}\right)$, and the carborane backbone gave rise to a series of strong bands around $2590 \mathrm{~cm}^{-1}\left(v_{\mathrm{B}-\mathrm{H}}\right)$ [22]. In the mass spectrum of 4 , the highest molecular mass peak at $m / z 426$ (60\% rel. int.) could be assigned to the ion $[\mathrm{M}-\mathrm{Cl}]^{+}$. 


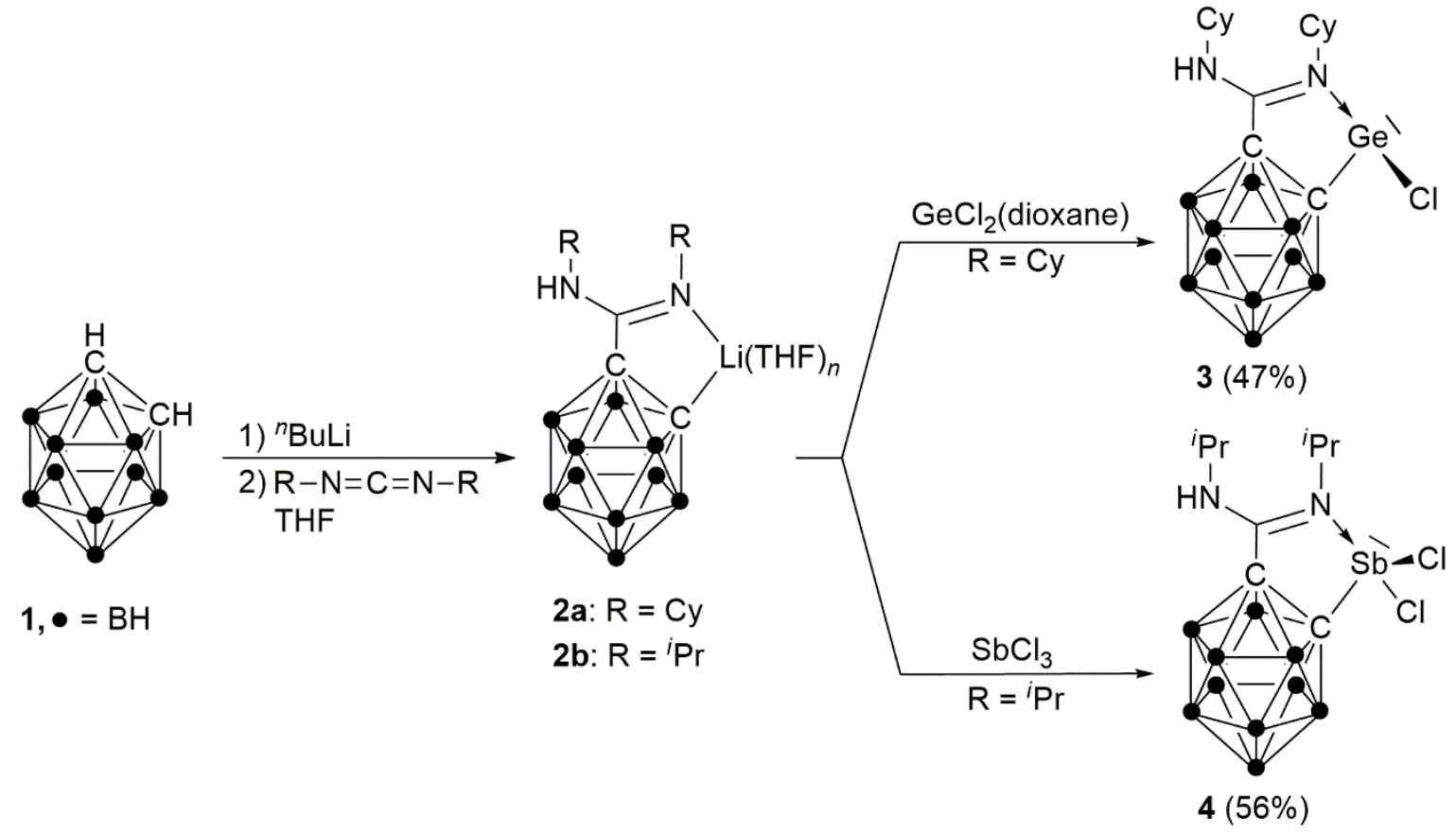

Scheme 2. Synthetic route to the title compounds 3 and 4 .

\subsection{Crystal and Molecular Structures}

Both title compounds 3 and $\mathbf{4}$ crystallize from toluene in solvent-free form with one monomeric molecule in the asymmetric unit. Crystal structure determinations confirmed the presence of one monoanionic carboranylamidinate ligand attached to the metal center in a typical $\kappa C, \kappa N$-chelating mode. The protonated NHR residue ( $3: \mathrm{R}=\mathrm{Cy} ; 4: \mathrm{R}={ }^{i} \mathrm{Pr}$ ) is directed away from the metal center and does not contribute to coordinative saturation thereof. Both 3 and 4 exist as the antirotamer in the crystal (relating to the orientation of the NHR group relative to the carboranyl group). In both compounds, the $\mathrm{C}-\mathrm{N}$ bond to the metal-attached nitrogen (N1) is shorter than the $\mathrm{C}-\mathrm{N}$ bond to the protonated nitrogen (N2), which is in agreement with the presence of a formal double bond between $\mathrm{C} 1$ and N1. The observed $\mathrm{C}-\mathrm{N}$ distances resemble those observed in previously described complexes with [HL] $]^{-}$ligands [21,22].

In the germanium(II) derivative 3, the stereo-active lone pair leads to a trigonal-pyramidal coordination environment of the Ge center (Figure 1). At 204.0(5) and 229.4(2) pm, respectively, the $\mathrm{Ge}-\mathrm{C}$ and $\mathrm{Ge}-\mathrm{Cl}$ bond lengths are expectedly longer than in the previously reported germanium(IV) derivative $\mathrm{GeCl}_{3}\left[\mathrm{HL}^{i \mathrm{Pr}}\right]$ (Ge-C 195.6(2) pm, Ge-Cl 226.4(1) pm) [22]. However, the Ge-N distances are very similar in both compounds (3: 205.3(5) pm, $\mathrm{GeCl}_{3}\left[\mathrm{HL}^{i \mathrm{Pr}}\right]$ : 204.8(2) pm). Rather untypical for carboranylamidinates, the molecules in $\mathbf{3}$ are assembled through weak $\mathrm{N}-\mathrm{H} \cdots \mathrm{Cl}$ hydrogen bonds to infinite supramolecular chains (Figure 2). In the previously reported complexes with [HL] $]^{-}$-type ligands, no hydrogen bonding with participation of the amidine NH moiety has been observed [21,22].

In the antimony(III) derivative 4 , the central $\mathrm{Sb}$ atom displays a pseudo-trigonal-bipyramidal coordination by the $\kappa_{\mathrm{K}} \mathrm{KN}$-chelating $\left[\mathrm{HL}^{i \mathrm{Pr}}\right]^{-}$ligand, two chlorido ligands, and a stereo-active lone pair (Figure 3). The axial positions are occupied by the nitrogen donor (N1) and one of the chlorine atoms $(\mathrm{Cl} 2)$, with the N1-Sb1-Cl2 angle being $163.63(5)^{\circ}$. This assignment is in agreement with the $\mathrm{Sb} 1-\mathrm{Cl} 2$ bond lengths of 249.7(1) pm, which is considerably longer than the equatorial Sb1-Cl1 bond (234.8(1) pm). The Sb1-C3 bond is 218.6(2) pm and therefore slightly longer than the mean value for tetra-coordinated Sb(III) compounds in the Cambridge Structural Database (214 pm for 664 entries with $R_{1} \leq 0.075$ ) [26]. The same is true for the Sb1-N1 bond, which is 237.0(2) pm (mean value for 167 CSD entries with $R_{1} \leq 0.075: 230 \mathrm{pm}$ ) [26]. The molecular structure of 4 is closely related to those of the previously reported $\mathrm{ECl}_{3}[\mathrm{HL}]$ compounds $(\mathrm{E}=\mathrm{Ge}, \mathrm{Sn})[22]$, with one of the equatorial chlorido 
ligands being formally replaced by a lone pair. Different from 3 , the amidine NH moiety in 4 is not involved in hydrogen bonding.

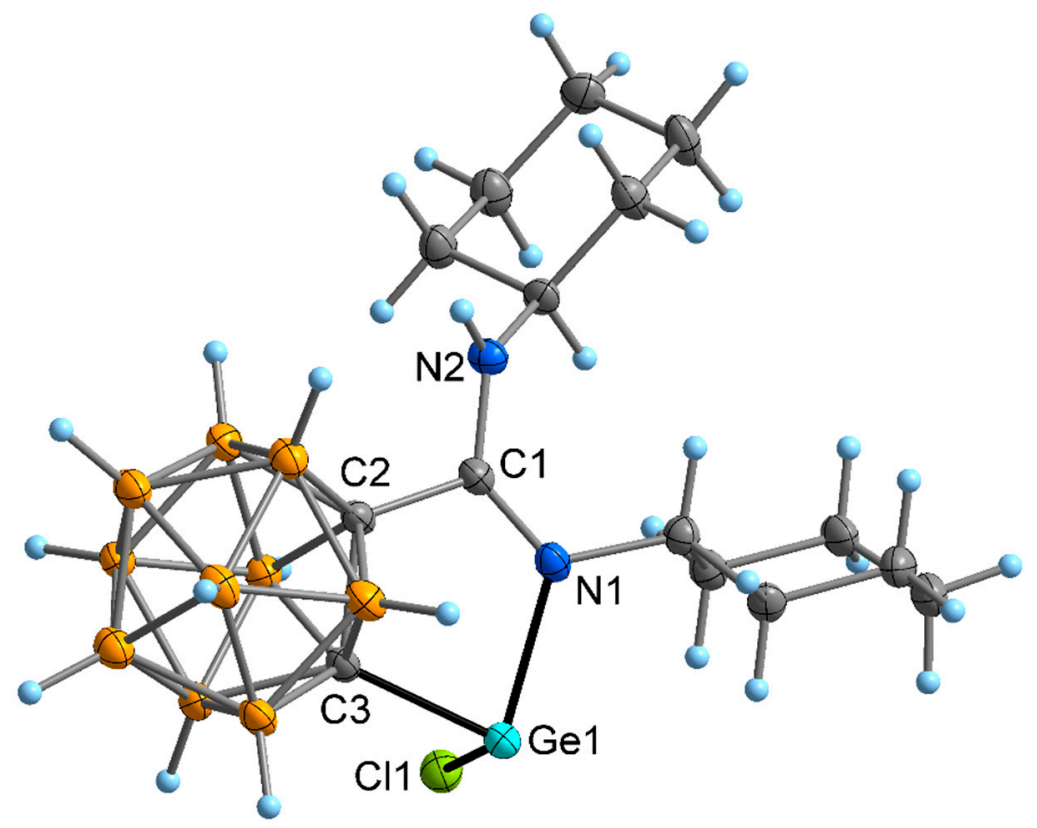

Figure 1. Molecular structure of 3 in the crystal. Displacement ellipsoids of the heavier atoms are drawn with 50\% probability. Selected bond lengths (pm) and angles (deg.): Ge1-C3 204.1(5), Ge1-N1 205.3(4), Ge1-Cl1 229.4(2), C3-Ge1-N1 82.5(2), C3-Ge1-Cl1 95.1(2), N1-Ge1-Cl1 97.3(1), C1-N1 130.3(7), C1-N2 133.2(7), C1-C2 150.8(7), N1-C1-N2 128.8(5).

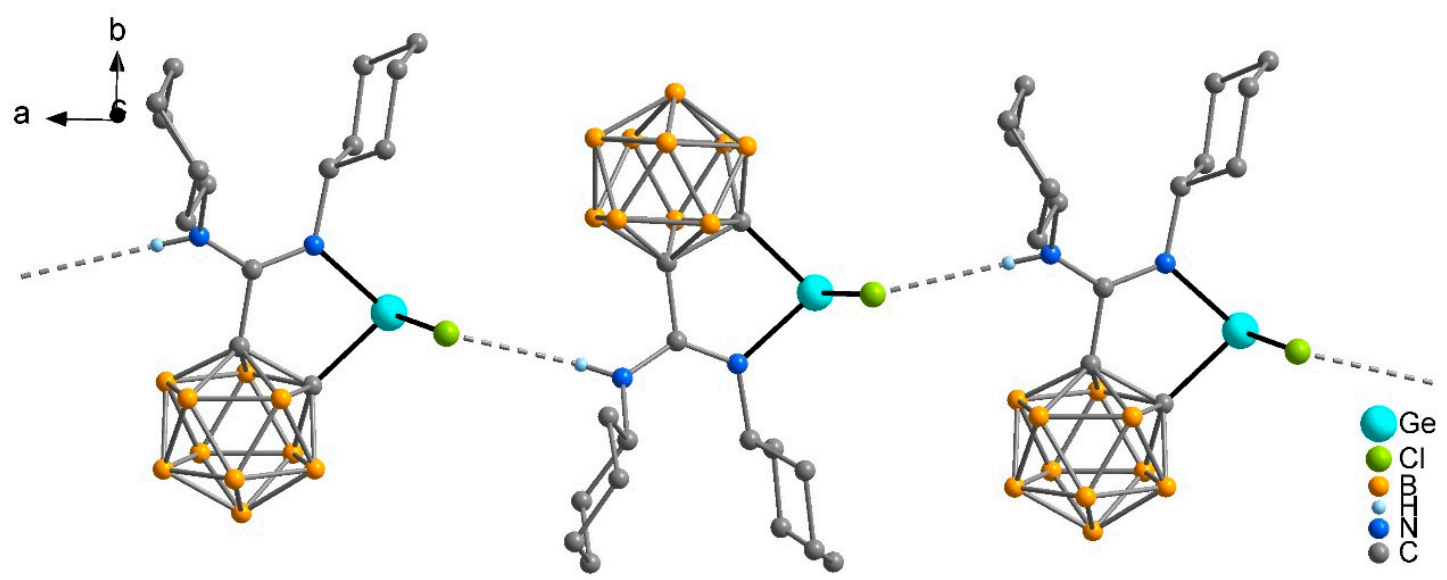

Figure 2. Hydrogen-bonded chain structure of 3 in the crystalline state. Hydrogen atoms attached to B and $\mathrm{C}$ atoms omitted for clarity. N2 $\cdots \mathrm{Cl} 1488.7(5) \mathrm{pm}, \mathrm{Cl} 1 \cdots \mathrm{H}$ approximately $268 \mathrm{pm}$. 


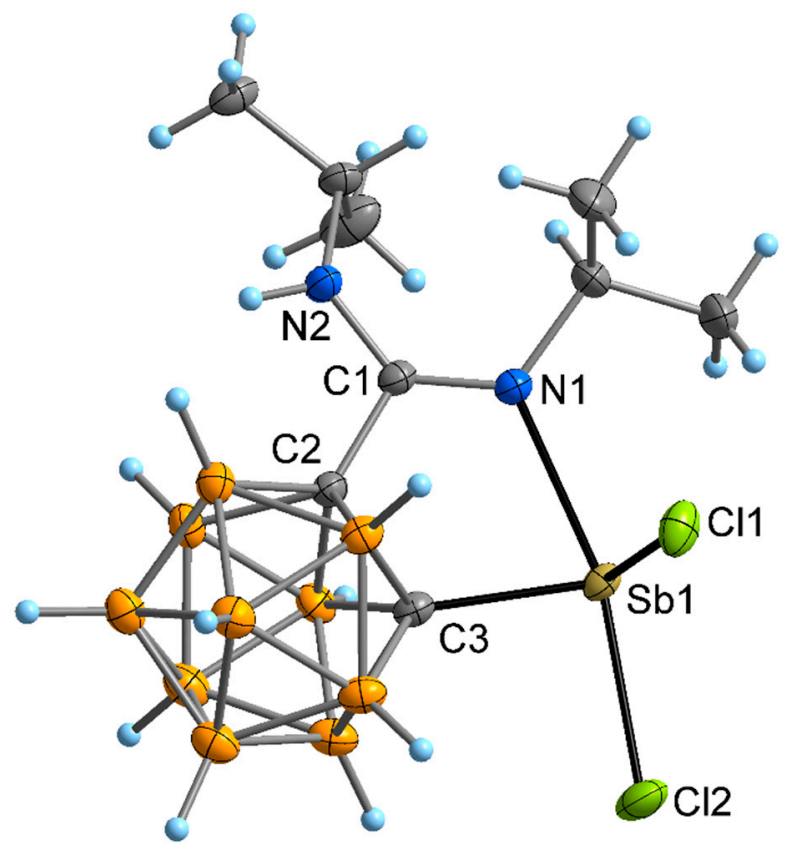

Figure 3. Molecular structure of 4 in the crystal. Displacement ellipsoids of the heavier atoms are drawn with 50\% probability. Selected bond lengths (pm) and angles (deg.): Sb1-C3 218.7(3), Sb1-N1 237.0(2), Sb1-Cl1 234.8(1), Sb1-Cl2 249.7(1), C3-Sb1-N1 75.44(8), C3-Sb1-Cl1 97.25(7), C3-Sb1-Cl2 88.75(7), N1-Sb1-Cl1 88.11(5), N1-Sb1-Cl2 163.63(5), Cl1-Sb1-Cl2 89.74(3), C1-N1 128.9(3), C1-N2 134.1(3), C1-C2 151.3(3), N1-C1-N2 130.8(2).

\section{Experimental Section}

\subsection{General Procedures and Instrumentation}

All reactions were carried out in oven-dried or flame-dried glassware under an inert atmosphere of dry argon employing standard Schlenk and glovebox techniques. The solvent THF was distilled from sodium/benzophenone under nitrogen atmosphere prior to use. $\mathrm{GeCl}_{2}$ (dioxane) was prepared according to a published procedure [25]. All other starting materials were purchased from commercial sources and used without further purification. ${ }^{1} \mathrm{H}-\mathrm{NMR}(400 \mathrm{MHz})$ and ${ }^{13} \mathrm{C}-\mathrm{NMR}(100.6 \mathrm{MHz})$ spectra were recorded in THF- $d_{8}$ solution on a Bruker DPX 400 spectrometer (Bruker BioSpin, Rheinstetten, Germany). IR spectra were measured with a Bruker Vertex 70V spectrometer (Bruker Optics, Rheinstetten, Germany) equipped with a diamond ATR unit between $4000 \mathrm{~cm}^{-1}$ and $50 \mathrm{~cm}^{-1}$. Microanalyses $(\mathrm{C}, \mathrm{H}, \mathrm{N})$ were performed using a VARIO EL cube apparatus (Elementar Analysensysteme, Langenselbold, Germany).

\subsection{Synthesis of Compound 3}

A solution of $\mathrm{Li}\left[\mathrm{HL}^{\mathrm{Cy}}\right]$ was prepared as described previously [8] by treatment of 1 (0.95 g, $6.56 \mathrm{mmol})$ in THF (50 mL) with a $2.5 \mathrm{M}$ solution of ${ }^{n} \mathrm{BuLi}$ in hexanes $(2.7 \mathrm{~mL}, 6.56 \mathrm{mmol})$ followed by addition of 1,3-dicyclohexylcarbodiimide (1.35 g, $6.56 \mathrm{mmol})$. After stirring for $2 \mathrm{~h}$ at r.t., $\mathrm{GeCl}_{2}$ (dioxane) $(1.52 \mathrm{~g}, 6.56 \mathrm{mmol}$ ) was added as a solid and stirring was continued for $24 \mathrm{~h}$. The reaction mixture was evaporated to dryness, and the solid residue was extracted with toluene $(2 \times 20 \mathrm{~mL})$. The combined extracts were filtered and the clear, yellow filtrate was concentrated to a total volume of ca. $10 \mathrm{~mL}$. Crystallization at r.t. for a few days afforded $3(1.39 \mathrm{~g}, 47 \%)$ as colorless, block-like, moisture-sensitive crystals. M.p. $177^{\circ} \mathrm{C}$ (dec. ca. $220^{\circ} \mathrm{C}$ ). Elemental analysis calculated for $\mathrm{C}_{15} \mathrm{H}_{33} \mathrm{~B}_{10} \mathrm{ClGeN}_{2}\left(457.59 \mathrm{~g} \cdot \mathrm{mol}^{-1}\right)$ : $\mathrm{C}, 39.37 ; \mathrm{H}, 7.27 ; \mathrm{N}, 6.12$; found $\mathrm{C}, 38.88 ; \mathrm{H}, 7.20 ; \mathrm{N}, 5.99 .{ }^{1} \mathrm{H}$ NMR (400.1 MHz, THF- $\left.d_{8}, 23^{\circ} \mathrm{C}\right): \delta 8.06(\mathrm{~s}, \mathrm{NH}), 3.30-3.22(\mathrm{~m}, \mathrm{CH}), 3.15-3.03(\mathrm{~m}, \mathrm{CH}), 1.85-0.67(\mathrm{~m}$, $\mathrm{Cy} / \mathrm{BH}) \mathrm{ppm} .{ }^{13} \mathrm{C}$ NMR $\left(100.6 \mathrm{MHz}, \mathrm{THF}-d_{8}, 23{ }^{\circ} \mathrm{C}\right): \delta 157.5(\mathrm{CN}(\mathrm{NH})), 56.0(\mathrm{CH}), 53.8(\mathrm{CH}), 34.3(\mathrm{Cy})$, 
26.2 (Cy) ppm. IR (ATR): $v 3403 \mathrm{w}\left(v_{\mathrm{N}-\mathrm{H}}\right), 3305 \mathrm{w}, 3066 \mathrm{w}, 2929 \mathrm{~m}, 2854 \mathrm{~m}\left(v_{\mathrm{B}-\mathrm{H}}\right), 2634 \mathrm{w}, 2582 \mathrm{~s}, 2113$ $\mathrm{w}, 1661 \mathrm{w}, 1577 \mathrm{~s}\left(v_{\mathrm{C}=\mathrm{N}}\right), 1531 \mathrm{~s}, 1464 \mathrm{w}, 1449 \mathrm{~m}, 1366 \mathrm{w}, 1348 \mathrm{w}, 1332 \mathrm{~m}, 1300 \mathrm{w}, 1260 \mathrm{w}\left(v_{\mathrm{C}-\mathrm{N}}\right), 1243 \mathrm{w}$, 1229 w, 1192 w, 1146 w, 1078 m, 1059 m, 1042 m, 1022 m, 973 w, 940 w, 921 w, 907 w, 890 m, 868 w, 843 m, 820 m, 799 w, 790 w, 767 w, 729 m, 718 m, 693 m, 656 m, 593 w, 558 w, 541 w, 507 w, 480 w, 446 w, $410 \mathrm{w}, 380 \mathrm{w}, 361 \mathrm{w}, 300 \mathrm{~s}, 266 \mathrm{~s}, 227 \mathrm{~m}, 197 \mathrm{~m}, 176 \mathrm{~m}, 158 \mathrm{~m}, 121 \mathrm{~m}, 113 \mathrm{~m}, 98 \mathrm{~m}, 75 \mathrm{~m}, 66 \mathrm{~m} \mathrm{~cm}^{-1}$. MS (EI): $m / z(\%) 457(87)[\mathrm{M}-\mathrm{H}]^{+}, 422(13)[\mathrm{M}-\mathrm{Cl}]^{+}, 367(47)[\mathrm{M}-\mathrm{Cy}+\mathrm{H}]^{+}, 351(14)[\mathrm{M}-\mathrm{GeCl}]^{+}$, 339 (17) $[\mathrm{M}-\mathrm{Cy}-\mathrm{Cl}]^{+}, 295$ (60) $[\mathrm{M}-2 \mathrm{Cy}]^{+}, 269$ (69) $[\mathrm{M}-\mathrm{GeCl}-\mathrm{Cy}]^{+}, 255$ (100) $\left[\mathrm{C}_{4} \mathrm{H}_{7}\right]^{+}, 83$ (83) $[\mathrm{Cy}]^{+}, 187(60)[\mathrm{M}-\mathrm{GeCl}-2 \mathrm{Cy}+2 \mathrm{H}]^{+}, 98(26)[\mathrm{NCy}+\mathrm{H}]^{+}, 58(16)[\mathrm{M}-\mathrm{Cl}-2 \mathrm{Cy}+\mathrm{H}]^{+}$.

\subsection{Synthesis of Compound 4}

In a similar manner as for 3 , a solution of $\mathrm{Li}\left[\mathrm{HL}^{i \mathrm{Pr}}\right]$ was prepared from $\mathbf{1}(0.95 \mathrm{~g}, 6.56 \mathrm{mmol})$ in $\mathrm{THF}$ $(50 \mathrm{~mL})$, a $2.5 \mathrm{M}$ solution of ${ }^{n} \mathrm{BuLi}$ in hexanes $(2.7 \mathrm{~mL}, 6.56 \mathrm{mmol})$ and 1,3-diisopropylcarbodiimide $(0.83 \mathrm{~g}, 1 \mathrm{~mL}, 6.56 \mathrm{mmol})$ [8]. The addition of solid $\mathrm{SbCl}_{3}(1.50 \mathrm{~g}, 6.56 \mathrm{mmol})$ produced a yellow solution and precipitation of a small amount of black solid (presumably Sb). Work-up as described for 3 afforded compound 4 as colorless, needle-like, moisture-sensitive crystals in 56\% isolated yield (1.70 g). M.p. $141^{\circ} \mathrm{C}$. Elemental analysis calculated for $\mathrm{C}_{9} \mathrm{H}_{25} \mathrm{~B}_{10} \mathrm{Cl}_{2} \mathrm{~N}_{2} \mathrm{Sb}\left(462.07 \mathrm{~g} \cdot \mathrm{mol}^{-1}\right)$ : $\mathrm{C}, 23.39$; $\mathrm{H}, 5.45 ; \mathrm{N}, 6.06$; found $\mathrm{C}, 23.50 ; \mathrm{H}, 5.47 ; \mathrm{N}, 6.10 .{ }^{1} \mathrm{H}$ NMR $\left(400.1 \mathrm{MHz}, \mathrm{THF}-d_{8}, 23{ }^{\circ} \mathrm{C}\right): \delta 3.26(\mathrm{sept}, 2 \mathrm{H}$, $\mathrm{CH}, J=6.4 \mathrm{~Hz}$ ), 3.15 (sept, $2 \mathrm{H}, \mathrm{CH}, J=6.4 \mathrm{~Hz}), 1.48-1.16(\mathrm{br} \mathrm{m}, \mathrm{BH}), 0.86\left(\mathrm{~d}, 6 \mathrm{H}, \mathrm{CH}_{3}, J=6.4 \mathrm{~Hz}\right), 0.55$ $\left(\mathrm{d}, 6 \mathrm{H}, \mathrm{CH}_{3}, J=6.4 \mathrm{~Hz}\right) \mathrm{ppm} .{ }^{13} \mathrm{C}$ NMR $\left(100.6 \mathrm{MHz}, \mathrm{THF}-d_{8}, 23{ }^{\circ} \mathrm{C}\right): \delta 153.2(\mathrm{CN}(\mathrm{NH})), 50.3(\mathrm{CH}), 47.8$ (CH), $23.1\left(\mathrm{CH}_{3}\right), 23.0\left(\mathrm{CH}_{3}\right)$ ppm. IR (ATR): $v 3396 \mathrm{w}\left(v_{\mathrm{N}-\mathrm{H}}\right), 3375 \mathrm{w}, 2970 \mathrm{w}, 2930 \mathrm{w}, 2873 \mathrm{w}, 2599 \mathrm{~m}$, $2590 \mathrm{~m}\left(v_{\mathrm{B}-\mathrm{H}}\right), 2568 \mathrm{w}, 2113 \mathrm{w}, 1999 \mathrm{w}, 1738 \mathrm{w}, 1605 \mathrm{~m}\left(v_{\mathrm{C}=\mathrm{N}}\right), 1530 \mathrm{~m}, 1459 \mathrm{w}, 1390 \mathrm{w}, 1370 \mathrm{w}, 1333 \mathrm{w}$, $1289 \mathrm{w}, 1251 \mathrm{w}\left(v_{\mathrm{C}-\mathrm{N}}\right), 1159 \mathrm{w}, 1122 \mathrm{~m}, 1067 \mathrm{~m}, 1038 \mathrm{w}, 969 \mathrm{w}, 947 \mathrm{w}, 930 \mathrm{w}, 899 \mathrm{w}, 872 \mathrm{w}, 856 \mathrm{w}, 838 \mathrm{w}$, $815 \mathrm{w}, 760 \mathrm{w}, 735 \mathrm{w}, 681 \mathrm{w}, 665 \mathrm{w}, 634 \mathrm{w}, 621 \mathrm{w}, 597 \mathrm{w}, 575 \mathrm{w}, 555 \mathrm{w}, 539 \mathrm{w}, 517 \mathrm{w}, 480 \mathrm{w}, 455 \mathrm{w}, 412 \mathrm{w}$, $380 \mathrm{w}, 341 \mathrm{~m}, 303 \mathrm{w}, 249 \mathrm{~s}, 213 \mathrm{~m}, 193 \mathrm{~s}, 160 \mathrm{~s}, 141 \mathrm{~s}, 113 \mathrm{~s}, 78 \mathrm{~s} \mathrm{~cm}^{-1}$. MS (EI): $\mathrm{m} / z$ (\%) 426 (60) [M $-\mathrm{Cl}]^{+}, 368(31)\left[\mathrm{M}-\mathrm{Cl}-{ }^{i} \mathrm{Pr}-\mathrm{CH}_{3}\right]^{+}, 326(24)\left[\mathrm{Sb}\left(\mathrm{C}_{2} \mathrm{H}_{10} \mathrm{~B}_{10}\right) \mathrm{CNH}+\mathrm{H}\right]^{+}, 270(10)\left[\mathrm{M}-\mathrm{SbCl}_{2}\right]^{+}$, 256 (20) $\left[\mathrm{M}-\mathrm{SbCl}_{2}-\mathrm{CH}_{3}+\mathrm{H}\right]^{+}, 227$ (97) $\left[\mathrm{M}-\mathrm{SbCl}_{2}-{ }^{i} \mathrm{Pr}\right]^{+}, 213$ (18) $\left[\mathrm{M}-\mathrm{SbCl}_{2}-{ }^{i} \mathrm{Pr}-\mathrm{CH}_{3}+\right.$ $\mathrm{H}]^{+}, 192(54)\left[\mathrm{SbCl}_{2}\right]^{+}, 170(25)\left[\left(\mathrm{C}_{2} \mathrm{H}_{10} \mathrm{~B}_{10}\right) \mathrm{CNH}+\mathrm{H}\right]^{+}, 120(9)[\mathrm{Sb}]^{+}, 462(3)[\mathrm{M}]^{+}, 69(35)\left[\mathrm{CN}^{i} \mathrm{Pr}\right]^{+}, 58$ (100) $\left[\mathrm{HN}^{i} \mathrm{Pr}\right]^{+}$.

\subsection{X-ray Crystallography}

Single crystal X-ray intensity data of 3 and 4 were collected on a STOE IPDS 2T diffractometer [27] equipped with a $34 \mathrm{~cm}$ image plate detector, using graphite-monochromated Mo $\mathrm{K} \alpha$ radiation, at $T=100(2) \mathrm{K}$. The structure was solved by dual-space methods (SHELXT-2014/5) [28] and refined by full matrix least-squares methods on $F^{2}$ using SHELXL-2017/1 [29]. Crystallographic data for the compounds (see Supplementary Materials) have been deposited at the CCDC, 12 Union Road, Cambridge CB21EZ, UK. Copies of the data can be obtained free of charge on quoting the depository numbers 1899321 (3) and 1899321 (4) (Fax: +44-1223-336-033; E-Mail: deposit@ccdc.cam.ac.uk, http:/ /www.ccdc.cam.ac.uk).

\section{Conclusions}

To summarize the results reported here, two new carboranylamidinates of main group elements in low oxidation states were prepared and structurally characterized. Compound $\mathbf{3}$ represents the first carboranylamidinate species containing divalent germanium, while 4 is the first antimony carboranylamidinate. Both compounds were formed in a straightforward manner from the corresponding $\mathrm{Li}[\mathrm{HL}]$ derivative, and no products containing dianionic $[\mathrm{L}]^{2-}$ ligands were obtained. This finding meets the expectation in view of the previously discussed influence of the "hardness" of the central atom on the resulting product [22], as $\mathrm{Ge}(\mathrm{II})$ and $\mathrm{Sb}$ (II) are rather soft. In both products, the molecular geometries are governed by a stereo-active lone pair at the metal centers. Due to their chloro functions, both compounds should be promising starting materials for further derivative chemistry. 
Supplementary Materials: The following are available online at http:/ /www.mdpi.com/2304-6740/7/3/41/s1: Cif and Checkcif files for 3 and 4.

Author Contributions: N.H. and F.Z. performed the experimental work. P.L. and F.E. carried out the crystal structure determinations. L.H. measured the IR and NMR spectra, and S.B. measured the mass spectra and carried out the elemental analyses. F.T.E. conceived and supervised the experiments. F.T.E. and P.L. wrote the paper.

Acknowledgments: This work was financially supported by the Otto-von-Guericke-Universität Magdeburg.

Conflicts of Interest: The authors declare no conflict of interest.

\section{References}

1. Zakharkin, L.I.; Stanko, V.I.; Brattsev, V.A.; Chapovskii, Y.A.; Okhlobystin, O.Y. Synthesis of a new class of organoboron compounds, $\mathrm{B}_{10} \mathrm{C}_{2} \mathrm{H}_{12}$ (barene) and its derivatives. Russ. Chem. Bull. 1963, 12, 2074. [CrossRef]

2. Brown, A.D.; Colquhoun, H.M.; Daniels, A.J.; MacBride, J.A.H.; Stephenson, I.R.; Wade, K. Polymers and ceramics based on icosahedral carboranes. Model studies of the formation and hydrolytic stability of aryl ether, ketone, amide and borane linkages between carborane units. J. Mater. Chem. 1992, 2, $793-804$. [CrossRef]

3. Belmont, J.A.; Soto, J.; King, R.E., III; Donaldson, A.J.; Hewes, J.D.; Hawthorne, M.F. Metallacarboranes in catalysis. 8. I: Catalytic hydrogenolysis of alkenyl acetates. II: Catalytic alkene isomerization and hydrogenation revisited. J. Am. Chem. Soc. 1989, 111, 7475-7486. [CrossRef]

4. Teixidor, F.; Flores, M.A.; Viñas, C.; Kivekäs, R.; Sillanpää, R. [Rh(7-SPh-8-Me-7,8- $\left.\left.\mathrm{C}_{2} \mathrm{~B}_{9} \mathrm{H}_{10}\right)\left(\mathrm{PPh}_{3}\right)_{2}\right]: \mathrm{A} \mathrm{New}$ Rhodacarborane with Enhanced Activity in the Hydrogenation of 1-Alkenes. Angew. Chem. Int. Ed. 1996, 35, 2251-2253. [CrossRef]

5. Ferlekidis, A.; Goblet-Stachow, M.; Liégeois, J.F.; Pirotte, B.; Delarge, J.; Demonceau, A.; Fontaine, M.; Noels, A.F.; Chizhevsky, I.T.; Zinevich, T.V.; et al. Ligand effects in the hydrogenation of methacycline to doxycycline and epi-doxycycline catalysed by rhodium complexes molecular structure of the key catalyst [closo-3,3-( $\left.\eta^{2,3}-\mathrm{C}_{7} \mathrm{H}_{7} \mathrm{CH}_{2}\right)-3,1,2-\mathrm{RhC}_{2} \mathrm{~B}_{9} \mathrm{H}_{11}$ ]. J. Organomet. Chem. 1997, 536/537, 405-412. [CrossRef]

6. Vaillant, J.F.; Guenther, K.J.; King, A.S.; Morel, P.; Schaffer, P.; Sogbein, O.O.; Stephenson, K. The medicinal chemistry of carboranes. Coord. Chem. Rev. 2002, 232, 173-230. [CrossRef]

7. Murophy, D.M.; Mingos, D.M.P.; Haggitt, J.L.; Poell, H.R.; Westcott, S.A.; Marder, T.B.; Taylor, N.J.; Kanis, D.R. Synthesis of icosahedral carboranes for second-harmonic generation. Part 2. J. Mater. Chem. 1993, 3, 139-148. [CrossRef]

8. Dröse, P.; Hrib, C.G.; Edelmann, F.T. Carboranylamidinates. J. Am. Chem. Soc. 2010, 132, $15540-15541$. [CrossRef]

9. Junk, P.C.; Cole, M.L. Alkali-metal bis(aryl)formamidinates: A study of coordinative versatility. Chem. Commun. 2007, 1579-1590. [CrossRef]

10. Edelmann, F.T. Chapter 3-Advances in the Coordination Chemistry of Amidinate and Guanidinate Ligands. Adv. Organomet. Chem. 2008, 57, 183-352.

11. Edelmann, F.T. Lanthanide amidinates and guanidinates in catalysis and materials science: A continuing success story. Chem. Soc. Rev. 2012, 41, 7657-7672. [CrossRef] [PubMed]

12. Deacon, G.B.; Hossain, M.E.; Junk, P.C.; Salehisaki, M. Rare-earth $N, N^{\prime}$-diarylformamidinate complexes. Coord. Chem. Rev. 2017, 340, 247-265. [CrossRef]

13. Yao, Z.-J.; Su, G.; Jin, G.-X. Versatile Reactivity of Half-Sandwich Ir and Rh Complexes toward Carboranylamidinates and Their Derivatives: Synthesis, Structure, and Catalytic Activity for Norbornene Polymerization. Chem. Eur. J. 2011, 17, 13298-13307. [CrossRef] [PubMed]

14. Yaso, Z.-J.; Xu, B.; Su, G.; Jin, G.-X. B-H bond activation half-sandwich Ir and Ru complexes containing carboranylamidinate selenolate ligands. J. Organomet. Chem. 2012, 721-722, 31-35.

15. Yalo, Z.-J.; Yue, Y.-J.; Jin, G.-X. C-C Bond Cleavage of Zwitterionic Carboranes Promoted by a Half-Sandwich Iridium(III) Compley. Chem. Eur. J. 2013, 19, 2611-2614.

16. Xu, B.; Yao, Z.-J.; Jin, G.-X. Reactivity of half-sandwich metal complexes with sterically encumbered N,N'-bis(2,6-diisopropylphenyl) group-substituted carboranylamidinate ligands. Russ. Chem. Bull. 2014, 63, 963-969. [CrossRef]

17. Hillebrand, P.; Hrib, C.G.; Harmgarth, N.; Jones, P.G.; Lorenz, V.; Kühling, M.; Edelmann, F.T. Carboranylamidinates of di- and trivalent iron. Inorg. Chem. Commun. 2014, 46, 127-129. [CrossRef] 
18. Rädisch, T.; Harmgarth, N.; Liebing, P.; Beltrán-Leiva, M.J.; Páez-Hernández, D.; Arratia-Pérez, R.; Engelhardt, F.; Hilfert, L.; Oehler, F.; Busse, S.; et al. Three new types of transition metal carboranylamidinate complexes. Dalton Trans. 2018, 47, 6666-6671. [CrossRef]

19. Yao, Z.-J.; Jin, G.-X. Synthesis, Reactivity, and Structural Transformation of Mono- and Binuclear Carboranylamidinate-Based 3d Metal Complexes and Metallacarborane Derivatives. Organometallics 2012, 31, 1767-1774. [CrossRef]

20. Harmgarth, N.; Gräsing, D.; Dröse, P.; Hrib, C.G.; Jones, P.G.; Lorenz, V.; Hilfert, L.; Busse, S.; Edelmann, F.T. Novel inorganic heterocycles from dimetalated carboranylamidinates. Dalton Trans. 2014, 43, 5001-5013. [CrossRef] [PubMed]

21. Harmgarth, N.; Liebing, P.; Hillebrand, P.; Busse, S.; Edelmann, F.T. Synthesis and crystals structures of two new tin bis(carboranylamidinate) complexes. Acta Crystallogr. Sect. E Crystallogr. Commun. 2017, 73, 1443-1448. [CrossRef]

22. Harmgarth, N.; Liebing, P.; Förster, A.; Hilfert, L.; Busse, S.; Edelmann, F.T. Spontaneous vs. base-induced dehydrochlorination of Group 14 ortho-carboranylamidinates. Eur. J. Inorg. Chem. 2017, 2017, 4473-4479. [CrossRef]

23. Edelmann, F.T. Carboranylamidinates. Z. Anorg. Allg. Chem. 2013, 639, 655-667. [CrossRef]

24. Yao, Z.-J.; Jin, G.-X. Transition metal complexes based on carboranyl ligands containing N, P, and S donors: Synthesis, reactivity and applications. Coord. Chem. Rev. 2013, 257, 2522-2535. [CrossRef]

25. Kolesnikov, S.P.; Rogozhin, I.S.; Nefedov, O.M. Preparation of complex of germanium bichloride with 1,4-dioxane. Bull. Acad. Sci. USSR Div. Chem. Sci. 1974, 23, 2297-2298. [CrossRef]

26. Groom, C.R.; Allen, F.H. The Cambridge Structural Database in retrospect and prospect. Angew. Chem. Int. Ed. 2014, 53, 662-671. [CrossRef] [PubMed]

27. Stoe \& Cie. X-Area and X-Red; Stoe \& Cie: Darmstadt, Germany, 2002.

28. Sheldrick, G.M. SHELXT-Integrated space-group and crystal-structure determination. Acta Cryst. 2015, A71, 3-8. [CrossRef] [PubMed]

29. Sheldrick, G.M. Crystal structures refinement with SHELXL. Acta Cryst. 2015, C71, 3-8. [CrossRef] [PubMed] 